\title{
Comparison of Diesel Engine Vibroacoustic Properties Powered by Bio and Standard Fuel
}

\author{
Radoslaw Wrobel ${ }^{1, *}$, Gustaw Sierzputowski ${ }^{1}$, Zbigniew Sroka ${ }^{1}$ (D) and Radostin Dimitrov ${ }^{2}$ (D) \\ 1 Division of Automotive Engineering, Faculty of Mechanical Engineering, \\ Wroclaw University of Science and Technology, W. Wyspianskiego 27, 50-370 Wroclaw, Poland; \\ gustaw.sierzputowski@pwr.edu.pl (G.S.); zbigniew.sroka@pwr.edu.pl (Z.S.) \\ 2 Department of Technical Engineering, Technical University of Varna, Studentska 1, 9010 Varna, Bulgaria; \\ r_dimitrov@tu-varna.bg \\ * Correspondence: radoslaw.wrobel@pwr.edu.pl; Tel.: +48-660-406-004
}

check for updates

Citation: Wrobel, R.; Sierzputowski, G.; Sroka, Z.; Dimitrov, R. Comparison of Diesel Engine Vibroacoustic Properties Powered by Bio and Standard Fuel. Energies 2021, 14, 1478. https://doi.org/10.3390/ en14051478

Academic Editor: Jacek Pielecha

Received: 11 February 2021

Accepted: 3 March 2021

Published: 8 March 2021

Publisher's Note: MDPI stays neutral with regard to jurisdictional claims in published maps and institutional affiliations.

Copyright: (c) 2021 by the authors. Licensee MDPI, Basel, Switzerland. This article is an open access article distributed under the terms and conditions of the Creative Commons Attribution (CC BY) license (https:// creativecommons.org/licenses/by/ $4.0 /)$.

\begin{abstract}
Alternative fuels appeared soon after the first internal combustion engines were designed. The history of alternative fuels is basically as long as the history of the automotive industry. Initially, fuels whose physicochemical properties allowed for a change in parameters of the combustion process in order to achieve greater efficiency and reliability were searched for. Nowadays, there are significantly more variables; in addition to the above mentioned parameters, alternative fuels are being sought that will ensure environmental protection during vehicle operation and improve the ergonomics of use. This article outlines the results of the authors' own comparative tests of vibrations of a vibroacoustic character. Based on a popular engine model, the vibration-acoustic responses of a system powered by two types of fuel, namely, diesel and biodiesel (B10), are compared. The research consists of comparing vibrations in both time and frequency domains. In the case of the time domain, the evaluation was performed with vibrations as a function of engine torque and speed. In the case of frequency analysis, the focus was on changes in the frequency response for the tested fuels. The research shows that the profile of vibroacoustic vibrations changes in the case of biodiesel power supply in relation to standard fuel. The vibration profile changes significantly as a function of speed and only slightly in relation to the engine load. The results presented in this article show different vibroacoustic responses of an engine powered by diesel and biodiesel; the change is minor for lower speeds but significant (other harmonics are dominant) for higher speeds (changes in the dominant harmonic magnitude of up to $10 \%$ at a crankshaft speed of $3000 \mathrm{rpm}$ ).
\end{abstract}

Keywords: alternative fuels; vibrations; engine; vibroacoustic

\section{Introduction}

The search for alternative drives for machines and vehicles arises from the need to protect human health and the environment. This need is additionally reinforced by predictions of depletion of crude oil deposits, which is the chemical base for fuels that are used for popular propulsion sources, such as internal combustion engines [1-3]. Research in this area follows two parallel paths. The first one related to engine construction improvement considering alternative fuels. The second assumes a partial or complete transition from internal combustion drive to hybrids or electric drive.

This paper is in line with the research work on alternative fuels, emphasizing the effects of their use by evaluating engine vibrations. The studies in this scope are connected with the research on the ergonomics of combustion engine exploitation carried out in the Department of Automotive Engineering of Wrocław University of Technology [4,5].

The aspect of ergonomics is an increasingly emphasized indicator for the user in the sustainable development of means of transport. The user, regardless of whether in their workplace or for private, individual use, wants comfort of use, which is expressed, among others, by the evaluation of vibrations [6-8]. In both cases, there are very clear 
legal regulations. Therefore, it is impossible not to test the vibrations of the machine or the vehicle, and especially the engine, which makes up the basic component of the drive system $[9,10]$. Engine vibrations are natural because they result mainly from the cyclic nature of the combustion process. This issue has been addressed by researchers, and results are presented in many papers. For example, in [11], an attempt was made to identify the relationship between engine block vibrations and heat exchange. On the other hand, in works $[12,13]$, the thermodynamic evaluation of combustion processes was made in relation to vibroacoustic signals. The description of the combustion process in a diesel engine in the context of vibration acceleration signals of the engine block was made in [14], and in [15], the general conditions of conducting an experiment with the use of the vibroacoustic technique to examine the characteristics of engine operation were described.

A significant amount of research comprises evaluation of the influence of construction, technology, and materials (from which crank-and-piston systems, timing systems, power supply systems, cooling systems, etc. are made) on engine vibrations or in this context, evaluation of engine construction and operation accuracy. Within this scope, in a number of papers in the literature, e.g., [16,17], a wide spectrum of vibroacoustic diagnostics is indicated in relation to the combustion engine as a complex construction-functional system. In [18], the authors conducted studies on structural changes in the timing system, resulting in changes in valve lash, and determined the relationship between that lash and engine vibrations. Paper [19] focuses on engine vibrations resulting from manufacturing and piston operation errors. The issues of wear and tear and durability of engine parts in the early stages of damage development are addressed in paper [20], where the relationship between wear and tear and engine vibrations is identified.

Vibrations affecting a person may be harmful, since if the ability to dampen vibrations in the human body is insufficient, mechanical damage (injuries) may occur. Psychological effects represent another type of hazard and are equally undesirable for human health and life. For this reason, vibrations are the subject of many studies that fit into the field of ergonomics, inter alia by adjusting the means of work and environmental conditions to the physical and mental capabilities of a person. In this regard, there is a strong connection with efficiency of work or leisure [21].

Both factors, i.e., human health and ergonomic efficiency of operation, are key factors in works focusing on environmental protection and efficiency improvement of internal combustion engines by using alternative fuels [22,23]. We view alternative fuel as any type of unconventional substance whose properties make it suitable to be used as a substitute for standard, commonly used fuel [24-26]. The progress in research in this area is so great that something that was an alternative fuel only 20 years ago today is already standard, for example, compressed natural gas. There are also fuels that have been widespread for years in particular regions of the world, while in others, they are only becoming fuel and are treated as alternatives, e.g., alcohols. Biofuels of the third generation, obtained from algae (especially algae) and microorganisms, are very promising forms of fuel alternativeness $[27,28]$. It is impossible not to mention in this discussion the fuels obtained according to Fisher-Tropsch technology [29-31].

A brand new chemical composition, as well as a mixture of standard fuel with an additive meeting the requirement of alternatives, can serve as alternative fuel. Alternative fuel additives have become a key subject of research in relation to diesel engines, which is the result of the origin of additives from cultivated plants and their application in agricultural machines, where the source of drive is primarily diesel engines. The positive results of these studies have led to the extension of alternative fuel application to road freight transport and then to all types of machines and vehicles-including passenger cars. Today, fuels that are mixtures of diesel and fatty acid methyl esters of plant origin are commonly used. Among the various relevant crops, rapeseed is most commonly used, but the additive can be made from sunflower oil, corn, jatropha, or palm oil. The complete or partial replacement of crude oil by cultivated plants provides an alternative and guarantees a positive environmental impact. 
The combination of research on alternative fuels and vibrations of engines powered by them is widely described in the literature. Many of those studies are aimed at characterizing the effects of different fuels on engine structure, including vibrations. For example, [32] deals with rapeseed oil methyl ester. In another paper [33], the compounds of sunflower and canola oils were explored. Engines powered by standard fuel and mixtures of standard fuel and fuel obtained from coal according to Fisher-Tropsch technology are tested in [34]. This paper demonstrates the full operational suitability of the tested blends. A broad analysis of various fuels in terms of their influence on engine vibrations is carried out in [35-37], whereas various techniques of vibration measurement, depending on the properties of biofuels, are the focus of works [38-40]. The study [41] narrows down the area of diagnostic research on the influence of biofuels on cylinder liners, and [42] discusses the issue of vibration testing of the entire engine block powered by alternative fuel.

The papers of the authors of this publication are of similar contents to those of the above-mentioned studies. The obtained results provide insight into vibroacoustic performance indicators of a diesel engine powered by standard fuel and biofuel.

The authors examined the vibrations of a combustion engine powered by standard diesel fuel and biofuel, commercially available as B10, i.e., with 10\% addition of rapeseed methyl ester. The engine operated under different load conditions and speeds, and the vibration acceleration was evaluated in terms of time and frequency. During the research, the focus was only on the maximum permissible amount of biocomponents (in the EU), amounting to $10 \%$ (the most commonly used values range from 5 to $7 \%$ ).

\section{Materials and Methods}

The aim of this work was to determine the influence of the biofuel (fuel mixture) on engine vibrations. The vibrations have a direct influence on machine gradation $[15,20,22,35]$ and ergonomics [6]. The research was carried out on a laboratory stand on a modern diesel engine powered with fuel, with a $10 \%$ addition of bio fuel and standard fuel as a reference point for discussion of the results. The engine vibrations on both power modes were measured by means of a measuring track with an acceleration sensor, signal transfer elements, and dedicated proprietary software. The methods of engine vibroacoustic testing are based on two methods: accelerometry [43,44] and laser vibrometry [17]. The vibroacoustic signal analysis has, to date, been based mainly on the Fourier transform (as in this article), but also on other transforms, such as wavelet transform (to date, used in non-stationary signal analysis) [12].

The test subject was a MultiJet Fiat 1.3 JTD (Jet Turbo Diesel) diesel engine featuring common-rail-type direct injection. This engine was selected for research not only due to the fact that it is produced exclusively in Poland but also due to its popularity in automotive applications of FCA group (Fiat Chrysler Automobiles), which includes brands such as Fiat, Lancia, Alfa Romeo, and Chrysler. It is also used in Opel and Suzuki vehicles. Moreover, in 2005, this engine won the Engine of the Year title in the category of engines with a displacement from 1.0 to $1.4 \mathrm{dm}^{3}$. Furthermore, in the following years, it served as a basis for the structural transformation that resulted in the engines MultiAir $1.4 \mathrm{dm}^{3}$ and TwinAir $0.875 \mathrm{dm}^{3}$, which proved to be successful in a subsequent international competition in 2010-2011. The technical specification of the tested engine model is presented in Table 1.

Throughout the tests, the engine was placed on a test stand equipped with a Schenck W150 electrowired brake, providing a load in full operating range-Figure 1.

The engine was powered by two types of fuel: standard diesel fuel and B10 blend (10\% rapeseed methyl ester, $90 \%$ conventional diesel). The selected physicochemical properties of the fuels used are presented in Table 2. The tests were performed according to the Worldwide Fuel Charter Sixth Edition Gasoline and Diesel Fuel-2019 [25] and the resulting standards, including the standard defining FAME ester content in fuel PN-EN 14103:2020-06 [26]. 
Table 1. The technical specification of the tested MultiJet 1.3 JTD (Jet Turbo Diesel) engine.

\begin{tabular}{cc}
\hline Parameter & Quantity \\
\hline Engine fuel type & Diesel \\
\hline Number of cylinders & Inline 4 \\
\hline Fuel system & Common Rail \\
\hline Aspiration & Turbo + intercooler \\
\hline Displacement, cc & 1248 \\
\hline Compression ratio & 18 \\
\hline Timing system & DOHC \\
\hline Number of valves & 16 \\
\hline Power, $\mathrm{kW}$ & $51 \approx 4000 \mathrm{rpm}$ \\
\hline Torque, Nm & $180 \approx 1750 \mathrm{rpm}$ \\
\hline Emission standard & Euro4
\end{tabular}

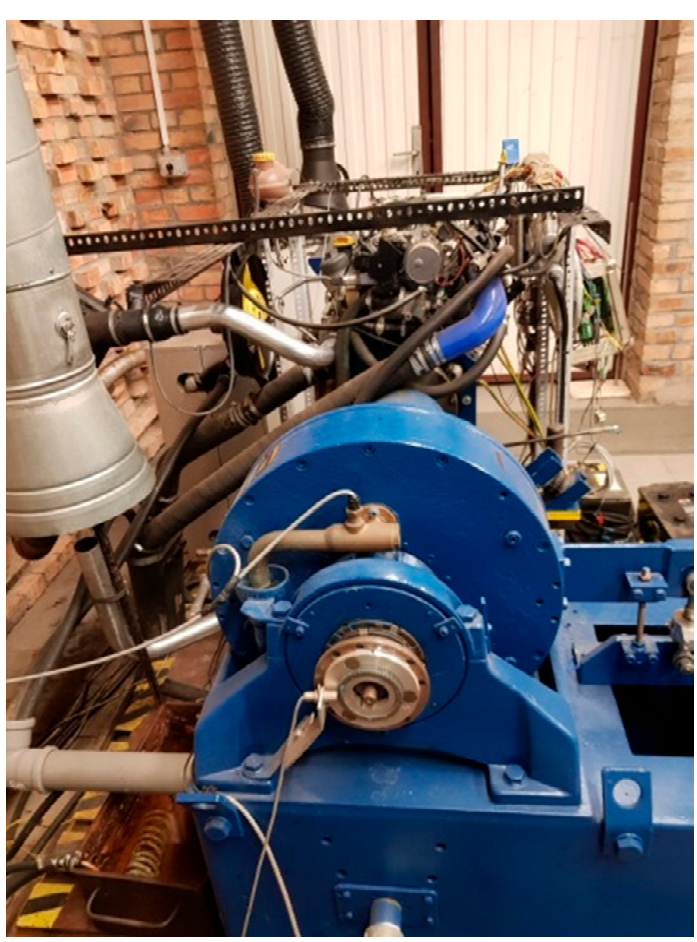

Figure 1. The test stand for the Fiat 1.3 JTD (Jet Turbo Diesel) engine at Wrocław University of Science and Technology.

Table 2. Selected physicochemical properties of the tested fuels.

\begin{tabular}{|c|c|c|c|c|c|c|c|c|}
\hline & \multirow{2}{*}{$\begin{array}{l}\text { Gross Heating } \\
\text { Value }\end{array}$} & \multirow{2}{*}{$\begin{array}{c}\text { Density } \approx \\
15^{\circ} \mathrm{C}\end{array}$} & \multirow{2}{*}{$\begin{array}{l}\text { Density } \approx \\
20^{\circ} \mathrm{C}\end{array}$} & \multicolumn{5}{|c|}{ Chemical Composition } \\
\hline & & & & Carbon & Hydrogen & Nitrogen & Sulfur & Oxygen \\
\hline & $\mathrm{kJ} / \mathrm{kg}$ & $\mathrm{g} / \mathrm{cm}^{3}$ & $\mathrm{~g} / \mathrm{cm}^{3}$ & $\%$ & $\%$ & $\%$ & $\%$ & $\%$ \\
\hline Standard fuel & 46,193 & 0.8280 & 0.8243 & 86.18 & 13.64 & 0.08 & 0.0004 & 0.10 \\
\hline Biodiesel B10 & 45,033 & 0.8420 & 0.8384 & 85.07 & 13.44 & 0.09 & 0.0004 & 1.40 \\
\hline
\end{tabular}


For vibration evaluation, a measuring track was used, consisting of a PCB 352C33 single-axis accelerometer (measurement range: $\pm 50 \mathrm{~g}$, sensitivity: $100 \mathrm{mV} / \mathrm{g}$, freq. range: 0.5 to $10 \mathrm{kHz}$ ), a NI 9234 data acquisition card (input voltage range: -5 to $5 \mathrm{~V}, 24 \mathrm{bit}$ analogue-to-digital converter, max. sample rate: $51.2 \mathrm{kS} / \mathrm{s}$, simultaneous sampling), and a computer with dedicated proprietary software. The accelerometer was mounted on the engine head, perpendicularly to the ground, on which the engine and dynamometer were mounted horizontally-Figure 2.

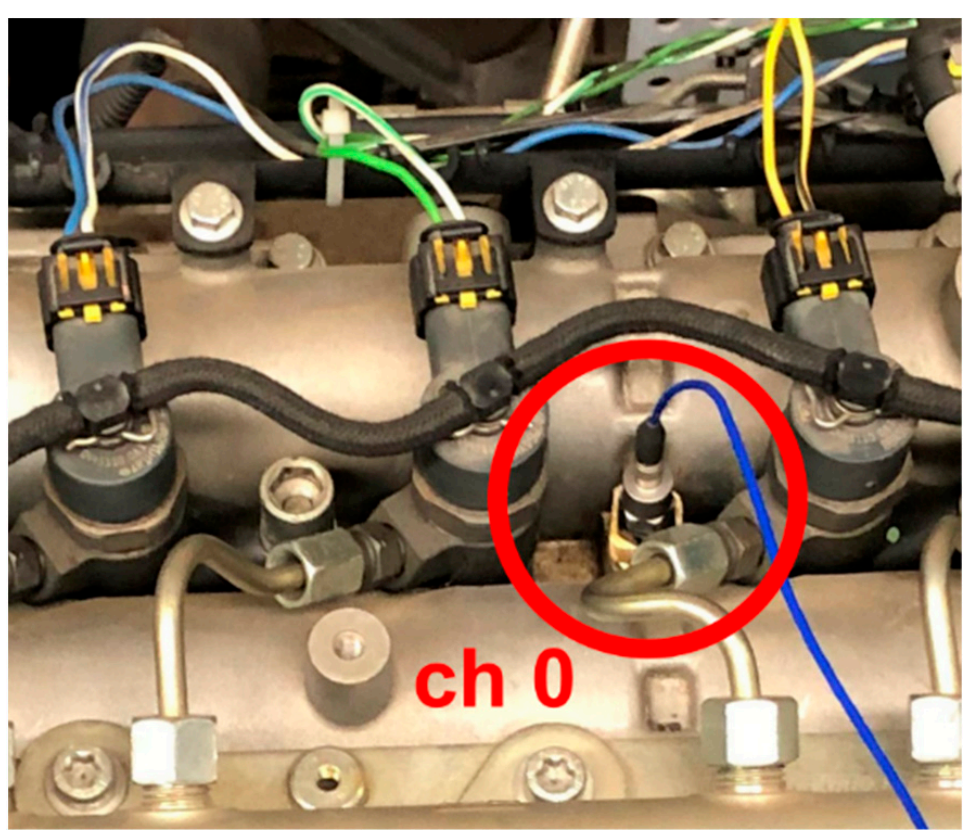

Figure 2. The acceleration sensor's mounting position on the Fiat 1.3 JTD engine head.

The measurements were made at the Niquista frequency equal to $8.5 \mathrm{kHz}$ [4], which enabled a proper conversion of the engine vibration signal to the frequency domain so as to obtain proper diagnostic information [45]. In order to make the measurement results more reliable, averaging of the individual harmonics was carried out on the basis of the shift theorem (1) $[6,45]$.

$$
X_{2}(m) \longleftrightarrow X_{1}(m) e^{j 2 \pi k^{m} / N}
$$

where:

$\mathrm{X}_{1}$ - the signal before the shift;

$X_{2}$-the signal after the shift;

$j$-the imaginary unit;

$\mathrm{k}$ - the number of samples by which signal $\mathrm{X} 2$ is shifted compared to signal $\mathrm{X} 1$;

$\mathrm{m}$ - the number of the considered sample;

$\mathrm{N}$ - the total number of samples recorded.

The shift theorem is particularly important when it comes to engine vibration analysis, as it enables tests to be carried out without having to start at the same point, e.g., always from TDC (Top Dead Center). If the point from which sampling is started is shifted by $\mathrm{k}$ samples from the previous sampling (resulting in an $X(\mathrm{~m})$ signal), then the shift after the transform will result in an $X(m) \exp (-j 2 \pi \mathrm{km} / N)$ signal. Assuming that the measurement lasts long enough and its parameters are properly selected, as a result of FFT (Fast Fourier Transform) transformation, a spectrum characterizing a given state of the tested object will be obtained.

In the time domain, the occurrence of maximum and minimum vibration values was investigated. In the frequency domain, after applying the FFT conversion [4,44], the 
difference between averaged periodograms an engine powered by conventional fuel and biodiesel was compared.

The tests were carried out for the full operational range of the engine, and they are qualitatively identical. To illustrate them, a representation of data related to the operating states typical of the tested engine was chosen. These are partial load characteristics at engine speeds of 1500 and $3000 \mathrm{rpm}$ for the loads of 10,50 and $100 \mathrm{Nm}$. The selected values represent the vehicle loads under operating conditions (they are in the range of $20-80 \%$ of the engine load).

\section{Results}

\subsection{Time Analysis}

The time analysis was based on a comparison of the maximum acceleration values in individual operating states. Figures 3 and 4 show examples of the vibration of the examined object in the time domain for different cases. Figure 3 shows the comparative periodograms for two different fuels, and Figure 4 documents the acceleration periodograms for one load at different engine speeds. The results of the tests, shown in Figure 3, indicate lower vibration acceleration values of the Fiat 1.3 JTD biofueled engine.

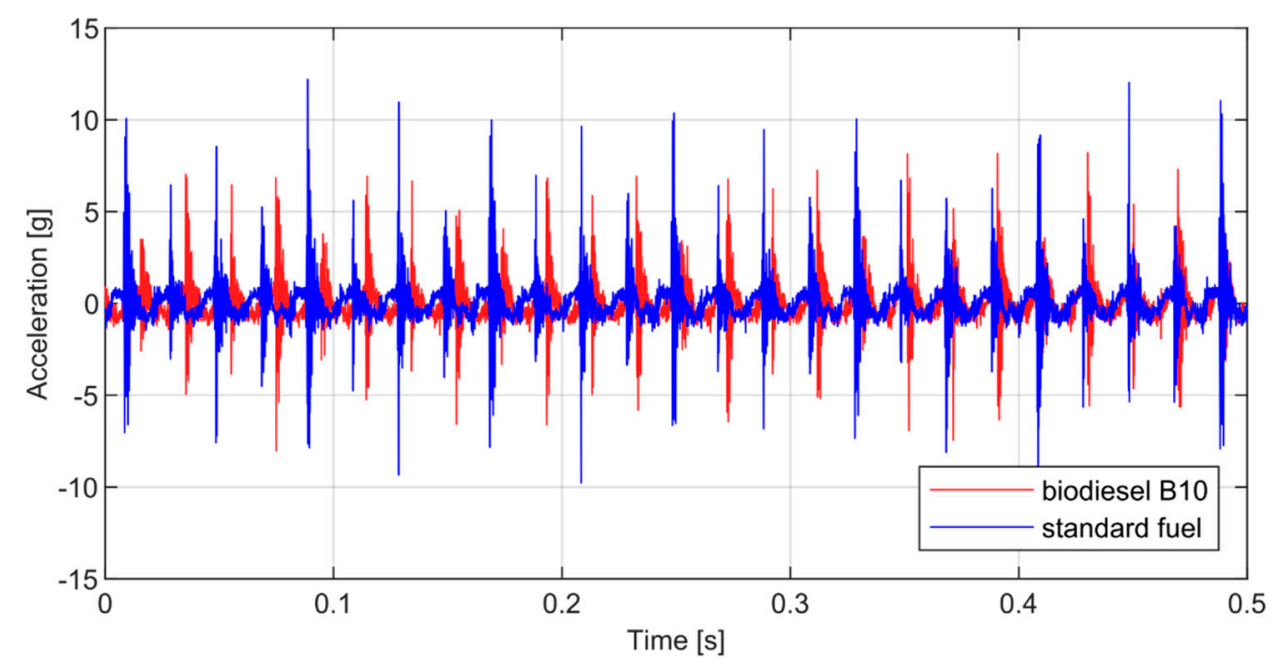

(a)

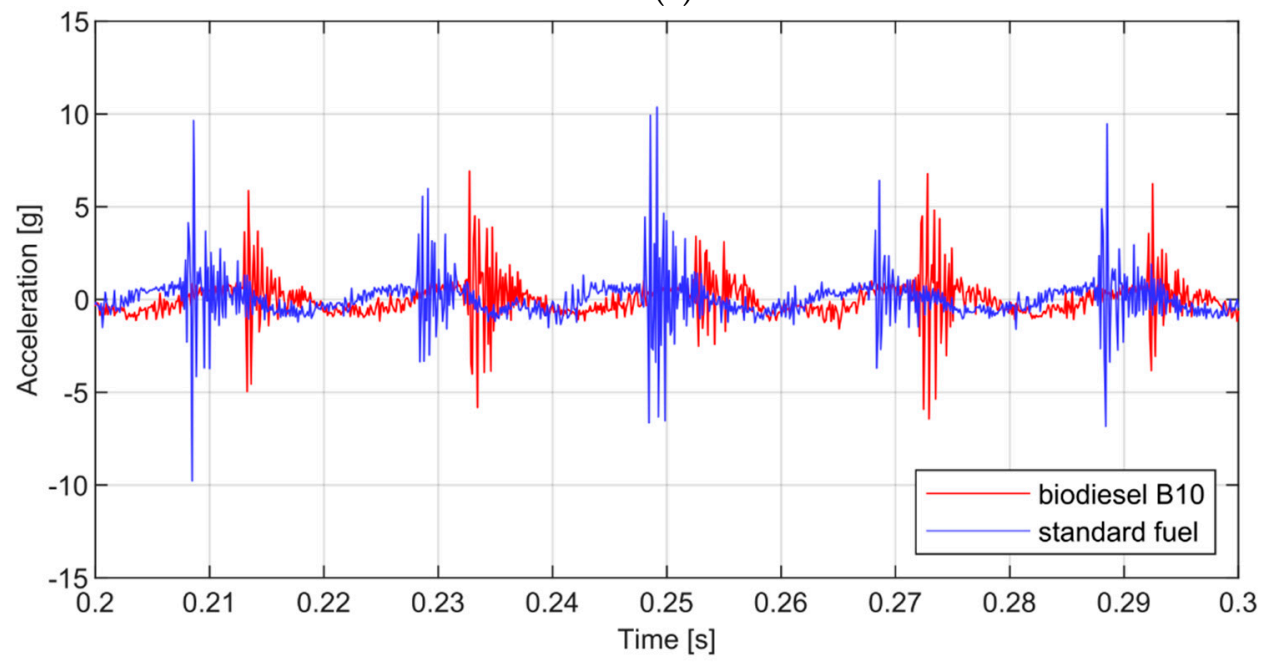

(b)

Figure 3. Comparison of Fiat 1.3 JTD engine vibration accelerations for $100 \mathrm{Nm}$ load at $1500 \mathrm{rpm}$ with standard fuel (red) and biodiesel B10 (blue) power; $\mathbf{a}-0.5 \mathrm{~s}$ time interval, $\mathbf{b}-0.1 \mathrm{~s}$ time interval. 


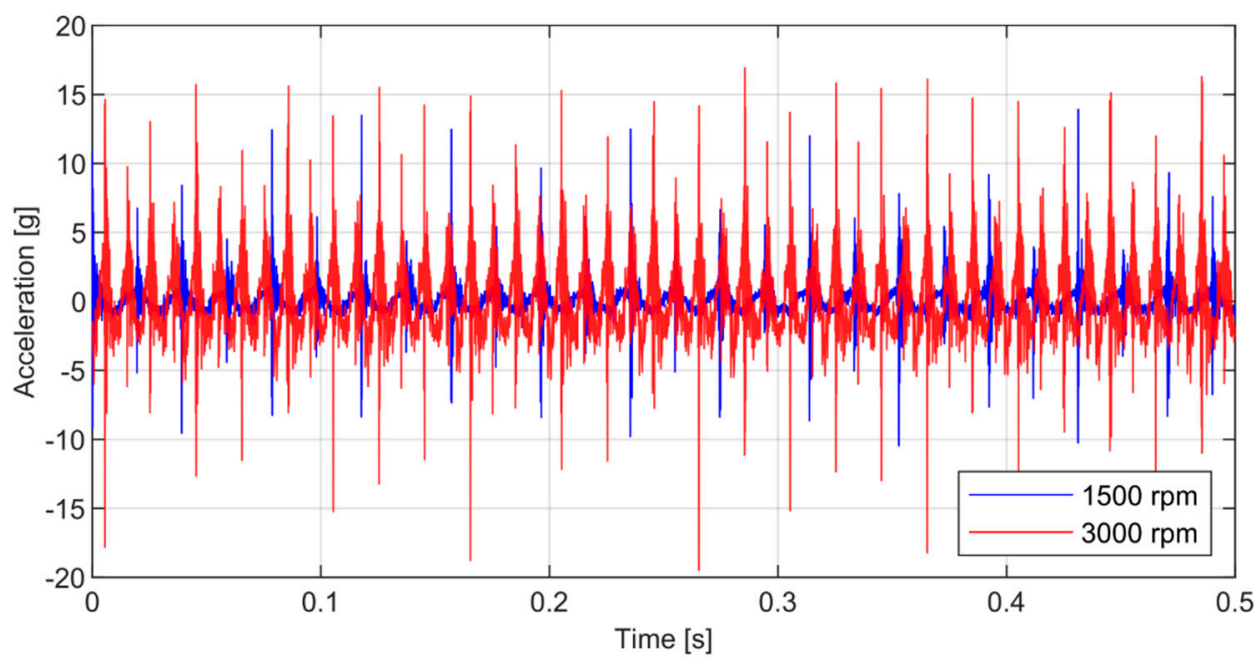

(a)

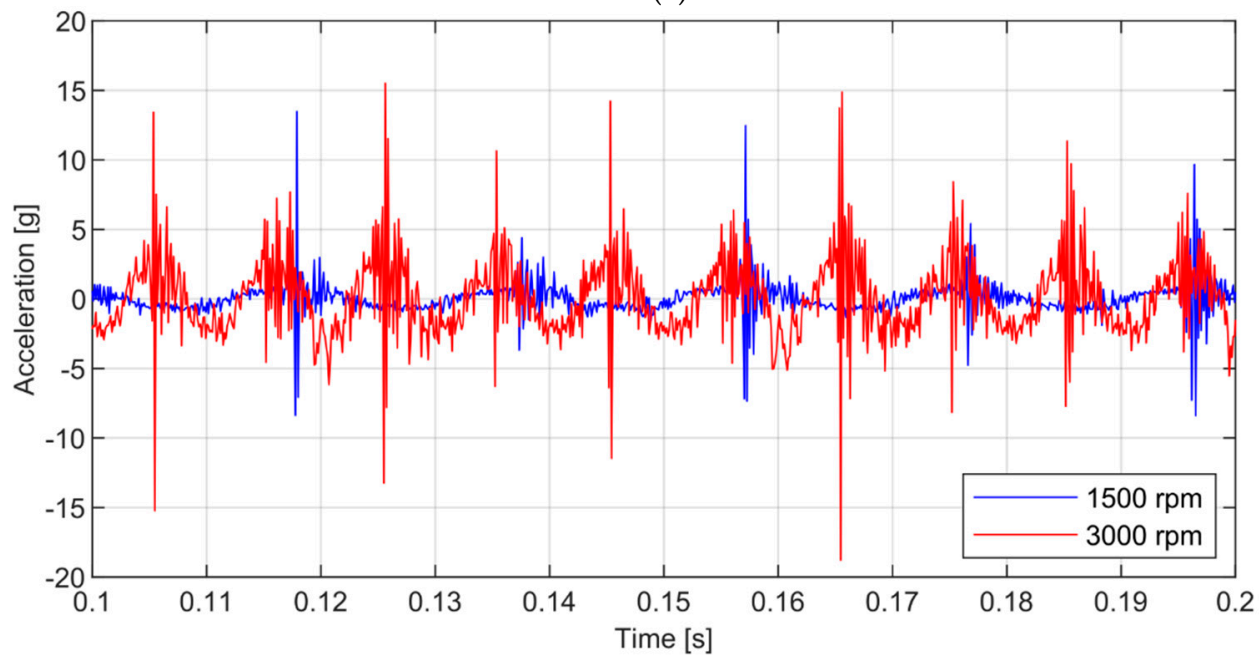

(b)

Figure 4. Comparison of the vibration acceleration plots for the Fiat $1.3 \mathrm{JTD}$ biodiesel B10 engine at $50 \mathrm{Nm}$ load and at different engine speeds: $1500 \mathrm{rpm}$ (blue) and $3000 \mathrm{rpm}$ (red); a-0.5 s time interval, $\mathbf{b}-0.1 \mathrm{~s}$ time interval.

The research results presented in Figure 4 show lower vibration acceleration values of the Fiat 1.3 JTD biofueled engine when it is run at a lower speed. The acceleration values distributed over time in both the first case (Figure 3) and the second case (Figure 4) confirm the assumption made in the methodology of the necessity to evaluate the operation states of the engine powered by different fuels by evaluating the average values. Hence, Figure 5 provides averaged maximum acceleration values for all tested engine operating states. Each measurement point was performed three times, and the time of a single measurement was $6 \mathrm{~s}$.

The analysis of the obtained results allowed us to identify the values of extreme vibration accelerations for the tested engine (Table 3, items 1 and 2), which is important in order to determine the range of the tested quantity. An interesting conclusion arises from averaging the maximum vibration acceleration values for different fuels when the analysis is carried out regardless of the engine speed and load. In both cases, the value oscillates at around $14.00 \mathrm{~g}$, making the difference negligible (Table 3, items 8 and 9). A further conclusion from the data in Table 4 regards the significance of the relationship between vibration acceleration and engine speed. For higher speeds, the vibration acceleration is greater. This is the case regardless of the fuel used (Table 3, items 3 and 4) as well as for the standard fuel (Table 3, items 10 and 11) but also for the biofuel supply (Table 3, items 12 and 13). When assessing the effect of the engine load on vibration acceleration, but regardless 
of the fuel type and speed (Table 3, items 5, 6, and 7), a relationship is obtained, which indicates that as the torque increases, the vibration acceleration rises. When examining the influence of the fuel independent of engine speed, it may be observed that the relationship between the load and vibration is no longer so strong, and by means of maximum values, it departs from the unambiguity (Table 3. Items 14-19).

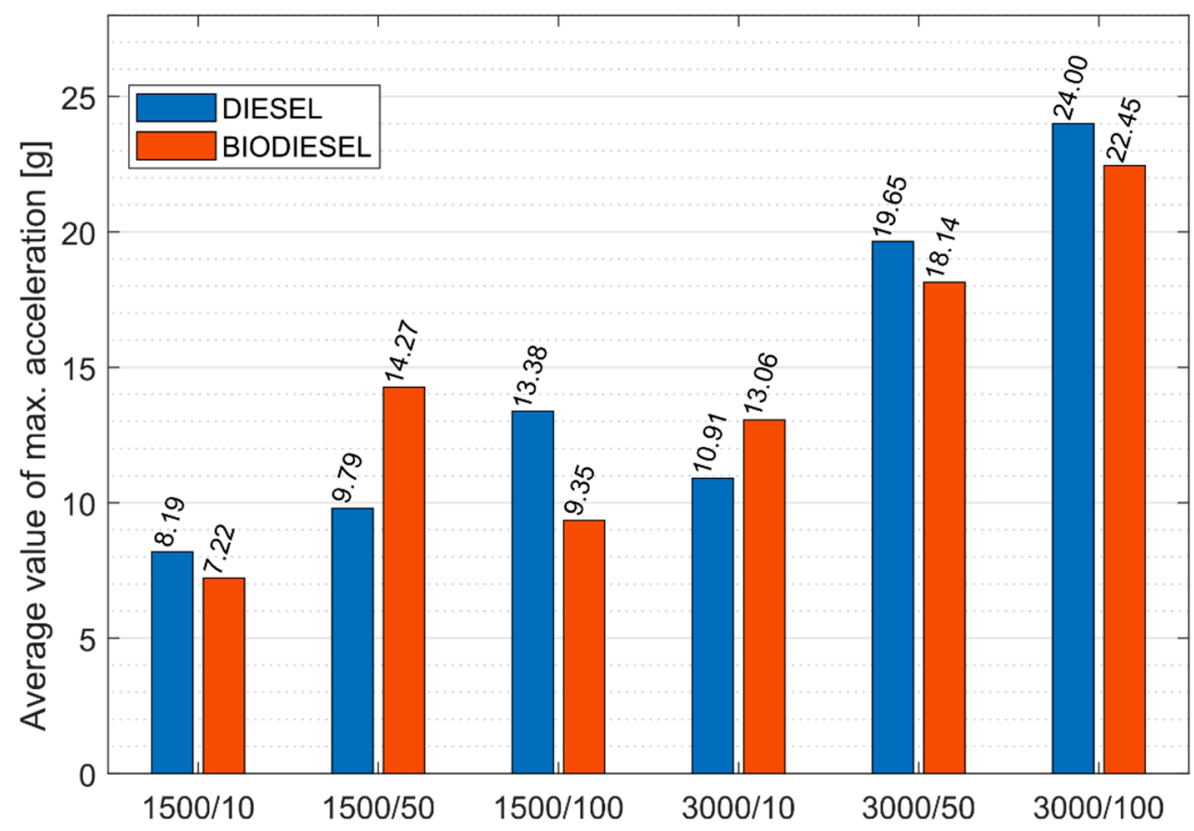

Figure 5. Averaged maximum vibration acceleration values for specific loads (Nm) and speeds (rpm).

Table 3. Matrix of averaged maximum vibration acceleration values.

\begin{tabular}{|c|c|c|c|c|}
\hline \multirow{2}{*}{ No. } & \multirow{2}{*}{ Fuel Type } & Engine Speed & Engine Torque & $\begin{array}{c}\text { Average Value of } \\
\text { Maximum Accelerations }\end{array}$ \\
\hline & & rpm & $\mathrm{Nm}$ & g \\
\hline 1. & \multirow{2}{*}{ Regardless } & \multirow{2}{*}{ Regardless } & \multirow{2}{*}{ Regardless } & $7.22-\mathrm{min}$ \\
\hline 2. & & & & $24.00-\max$ \\
\hline 3. & \multirow{2}{*}{ Regardless } & 1500 & \multirow{2}{*}{ Regardless } & 10.37 \\
\hline 4. & & 3000 & & 18.04 \\
\hline 5. & \multirow{3}{*}{ Regardless } & \multirow{3}{*}{ Regardless } & 10 & 9.85 \\
\hline 6. & & & 50 & 15.46 \\
\hline 7. & & & 100 & 17.30 \\
\hline 8. & Standard & \multirow{2}{*}{ Regardless } & \multirow{2}{*}{ Regardless } & 14.32 \\
\hline 9. & Biofuel & & & 14.08 \\
\hline 10. & \multirow{2}{*}{ Standard } & 1500 & \multirow{2}{*}{ Regardless } & 10.45 \\
\hline 11. & & 3000 & & 18.19 \\
\hline 12. & \multirow{2}{*}{ Biofuel } & 1500 & \multirow{2}{*}{ Regardless } & 10.28 \\
\hline 13. & & 3000 & & 17.88 \\
\hline 14. & \multirow{3}{*}{ Standard } & \multirow{3}{*}{ Regardless } & 10 & 9.55 \\
\hline 15. & & & 50 & 14.72 \\
\hline 16. & & & 100 & 18.69 \\
\hline
\end{tabular}


Table 3. Cont.

\begin{tabular}{|c|c|c|c|c|}
\hline No. & Fuel Type & Engine Speed & Engine Torque & $\begin{array}{c}\text { Average Value of } \\
\text { Maximum Accelerations }\end{array}$ \\
\hline & & rpm & $\mathrm{Nm}$ & g \\
\hline 17. & \multirow{3}{*}{ Biofuel } & \multirow{3}{*}{ Regardless } & 10 & 10.14 \\
\hline 18. & & & 50 & 16.21 \\
\hline 19. & & & 100 & 15.90 \\
\hline
\end{tabular}

Table 4. Relative changes in the average values of the selected engine performance indicators for the load characteristics.

\begin{tabular}{ccccc}
\hline $\begin{array}{c}\text { Engine Performance } \\
\text { Indicator }\end{array}$ & $\begin{array}{c}\text { Relative Change for } \\
\text { Biofuel Related to } \\
\text { Standard Fuel }\end{array}$ & Marking Error & $\begin{array}{c}\text { Comments Concerning } \\
\text { the Differences }\end{array}$ \\
\cline { 2 - 3 } $\begin{array}{c}\text { Engine Power } \\
\text { Specific fuel } \\
\text { consumption }\end{array}$ & -0.13 & 5 & Irrelevant \\
\hline $\begin{array}{c}\text { Engine-useful } \\
\text { efficiency }\end{array}$ & 1.31 & 1 & $\begin{array}{c}\text { Relevant } \\
\text { (the specific fuel } \\
\text { consumption of an engine } \\
\text { running on biofuel is } \\
\text { lower) }\end{array}$ \\
\hline Carbon monoxide & +3.88 & 1 & $\begin{array}{c}\text { Relevant } \\
\text { (the efficiency of the biofuel } \\
\text { engine is higher) }\end{array}$ \\
\hline Nitrogen oxides & +0.87 & 1 & $\begin{array}{c}\text { Irrelevant } \\
\text { (the NOx content of the } \\
\text { exhaust gas is significantly } \\
\text { higher for biofuel) }\end{array}$ \\
\hline
\end{tabular}

The collected results and the conclusions drawn by their evaluation are crucial due to their association with potential effects on the human body. These data may also be useful during subsequent upgrades of the tested drive unit.

\subsection{Frequncy Analysis}

The frequency analysis consisted of determining periodograms for individual states using a fast Fourier transform. Three measurement series were made for each state, and then the values of individual harmonics were averaged (Figure 6). In the next step, comparative characteristics were performed, in which the difference (delta a) of discrete harmonic values of the vibroacoustic signal coming from a diesel- and biodiesel-fueled object was included (which means that the flattened characteristics indicate very small changes in the vibroacoustic response for both fuels). Figure 7 shows the comparative characteristics of the tested operating states of the Fiat 1.3 JTD engine. 

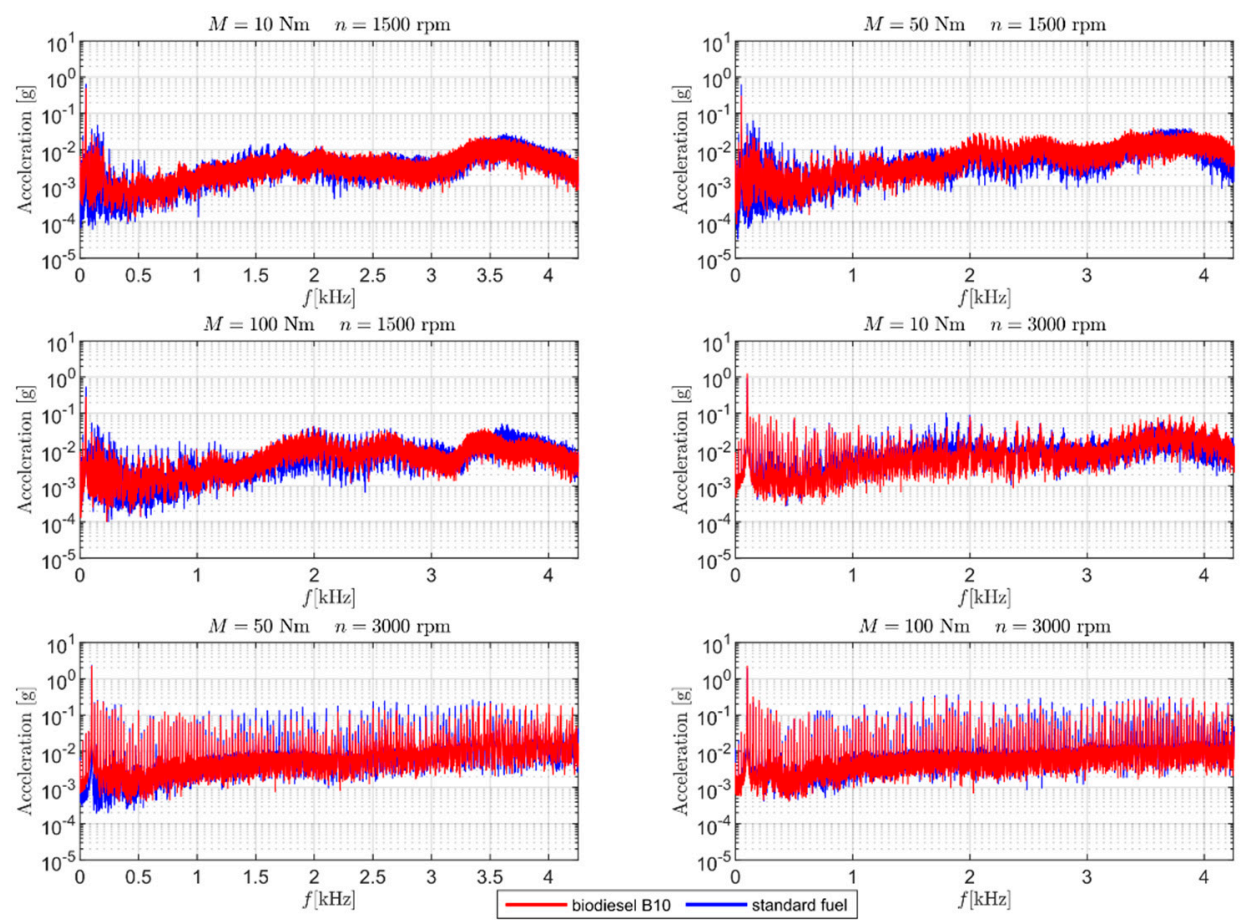

Figure 6. Comparison of the vibration accelerations in frequency domain for the Fiat 1.3 JTD at different engine loads and speeds with standard fuel (blue) and biodiesel B10 (red) power.
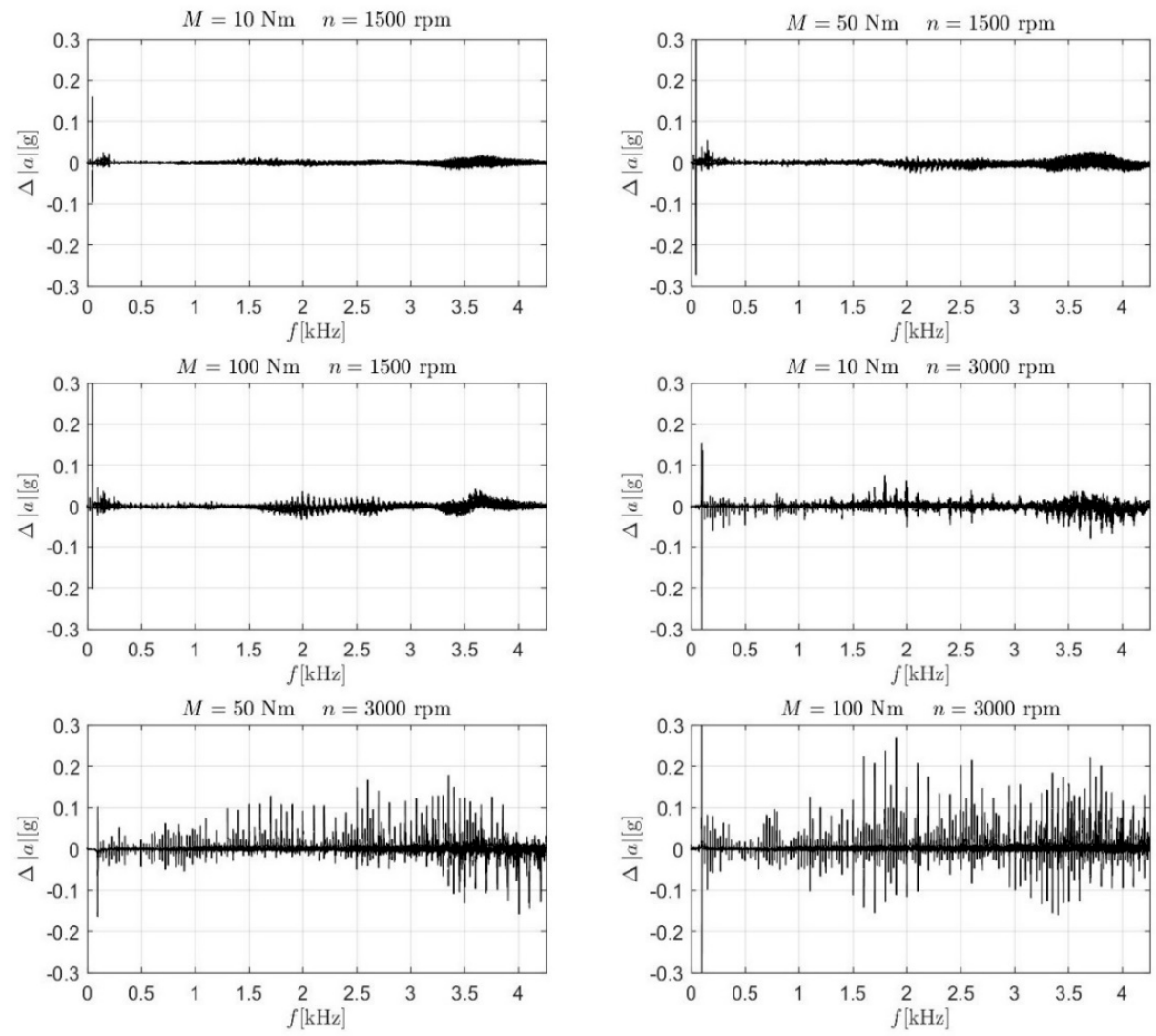

Figure 7. Comparative characteristics, including the difference $\left(\Delta a=a_{\text {diesel }}-a_{\text {biodiesel }}\right)$ of discrete harmonic values of the vibroacoustic signal coming from an object powered by biodiesel and diesel. 
Both the time analysis and frequency analysis indicate a strong dependence of vibrations and engine speed of the tested object on the fuel used. For the alternative fuel B10, the values of natural vibration acceleration together with the harmonics of the vibroacoustic signal are lower than those for the standard fuel. By analyzing previous research conducted by the authors of this paper [4,5] as well as other studies [11-14,32], the proven relationship is a result of the differences in the course of combustion processes for fuels with different carbon and hydrogen contents, but most of all, a highly significant difference in oxygen content-see Table 2. The data in Table 4, showing the relative changes in the selected engine performance indicators, provide supplementary data concerning fuel properties (Table 2), which may explain the differences in vibrations of the object powered by both standard fuel and biofuel and indicate a pro-ecological effect.

The emission measurements (Table 4) were made using the exhaust flow meter by AVL (model AVL M.O.V.E EFM). The device allows one to measure carbon monoxide with a display resolution of 1 ppm (accuracy 0-1499 ppm \pm 30 ppm abs.) and nitrogen oxides with a display resolution of $0.1 \mathrm{ppm}$ (accuracy $\pm 0.2 \%$ of full scale). The higher oxygen content of the biofuel accelerates combustion causes fewer carbon and hydrogen molecules to be surrounded by oxygen, thus making combustion fuller and more complete. A higher temperature and accompanying pressure, despite the lower calorific value of biofuel, result in a detonative shockwave due to auto-ignition. However, some of this fuel burns by deflagration when the chemical reaction is slower, and this is due to the higher density, which affects the droplet size. The acceleration of the combustion process combined with the shortening of the shock wavelength results in a reduction of engine vibrations, as shown in the time and frequency analyses. This is reflected in the changes in performance indicators, as shown in Table 4-lower specific fuel consumption and higher values of nitrogen oxides in the exhaust gases. The latter is not beneficial to human health and the environment, but knowing the essence of the changes, these values can be significantly reduced, e.g., by increasing the injection pressure and/or employing catalytic selective reduction systems.

\section{Conclusions}

The present paper contributes to a broad scientific research discussion on the application of biocomponents and their impact on drive unit operation. The paper compares vibroacoustic response of a system powered by two types of fuel: standard diesel and biodiesel with $10 \%$ addition of rapeseed methyl ester (B10). Biofuel is a commercial fuel; therefore, in addition to the scientific aspect, the study refers to the universality of use and utilitarianism of the conclusions made. The research involves comparing the vibrations in the in the domain of time as well as of frequency.

The time analysis indicates the difference in vibration amplitudes for individual loads. It can be observed that there is a higher vibration amplitude in the standard-powered engine at a higher engine speed (8\% for $3000 \mathrm{rpm} / 50 \mathrm{Nm}$ and 9\% for $3000 \mathrm{rpm} / 100 \mathrm{Nm}$ ). With lower load values, no significant changes indicating occurrence of a particular trend can be observed.

The frequency analysis results in a vibration profile change when operating on biodiesel and diesel. The change is minor for lower speeds but significant (other harmonics are dominant) for higher speeds.

In conclusion, it should be stated that the profile of vibroacoustic vibrations changes when operating on biodiesel and diesel. The fact that the vibration profile changes with speed when there is no or little correlation with the load is particularly notable. In practical terms, the results obtained show an ergonomic advantage of biofuels over standard fuel, manifested by a more favorable reduction of vibrations in different areas of the engine's full operational range. This may result in a transformation (tuning) of the universal engine characteristics, providing the user with vibroacoustic (ergonomic) comfort.

It is reasonable to infer that with the use of the latest artificial intelligence tools developed in recent years, it would be possible to employ engine vibration signals to 
precisely determine the type of fuel currently used. It is not difficult to imagine the huge potential that the proposed system would offer-from automatic adjustment of engine operation maps in terms of minimizing harmful emissions and, at the same time, maximizing the efficiency and durability of the engine, to the possibility of intelligent adaptation of motor vehicles to new, more ecological generations of biodiesel and quick identification of irregularities in the composition of the applied fuel, making it possible to prevent permanent engine damage or harmful emissions. Therefore, further research in the field of this study is planned in order to generate a sufficient amount of learning data and to attempt the development of the discussed identification system.

Author Contributions: Conceptualization, G.S., R.W. and R.D.; data curation, G.S.; formal analysis, R.W.; supervision, R.W. and Z.S. All authors have read and agreed to the published version of the manuscript.

Funding: This research was funded by Wroclaw University of Science and Technology, grant number N_PODST_BAD_EXP_BAM - 8211104160.

Institutional Review Board Statement: Not applicable.

Informed Consent Statement: Not applicable.

Data Availability Statement: The data presented in this study are available on request from the corresponding author. The data are not publicly available due to ongoing research.

Conflicts of Interest: The authors declare no conflict of interest.

\section{References}

1. Diesel: The true (dirty) story Transport \& Environment. Available online: https://www.transportenvironment.org/publications / diesel-true-dirty-story (accessed on 24 February 2021).

2. U.S. Energy Information Administration. Annual Energy Outlook 2019 with projections to 2050; U.S. Energy Information Administration: Washington, DC, USA, 2019.

3. Festel, G.W. Biofuels-Economic Aspects. Chem. Eng. Technol. 2008, 31, 715-720. [CrossRef]

4. Wróbel, R.S.; Łoza, Ł.; Haller, P.; Włostowski, R. The effect of fuel mixture on engine vibrations. Combust. Engines 2019, 177, 136-138.

5. Wróbel, R.S.; Kaźmierczak, A.; Krakowian, K. Doppler Laser Vibrometry in combustion engine's diagnosis. Przeglad Elektrotechniczny 2010, 86, 147-149.

6. Quintero, H.F.; López, J.F. Mechanical Vibrations: A theoretical-Practical Approach; Universidad Tecnológica de Pereira: Pereira, Risaralda, Colombia, 2016; pp. 1-348.

7. Singiresu, S.R. Mechanical Vibrations., 5th ed.; Pearson Education, Inc.: Upper Saddle River, NJ, USA, 2011.

8. Heidary, B.; Hassan-Beygi, S.R.; Ghobadian, B.; Taghizadeh, A. Vibration analysis of a small diesel engine using diesel-biodiesel fuel blends. Agric. Eng. Int. CIGR J. 2013, 15, 117-126.

9. Asahiro, N.S.; Bhosle, S.P.; Nehete, D.V. Dynamics and vibration Measurements in Engines. Procedia Manuf 2018, $20,434-439$.

10. Barelli, L.; Bidini, G.; Buratti, C.; Mariani, R. Diagnosis of internal combustion engine through vibration and acoustic pressure non-intrusive measurements. Appl Therm Eng 2009, 29, 1707-1713. [CrossRef]

11. Lee, S.; Lee, Y.; Lee, S.; Song, H.; Min, K.; Choi, H. Study on the Correlation between the Heat Release Rate and Vibrations from a Diesel Engine Block. In Proceedings of the SAE 2015 World Congress and Exhibition, Detroit, MI, USA, 21-23 April 2015; Society of Automotive Engineers: Warrendale, PA, USA, 2015.

12. Zhao, X.; Cheng, Y.; Ji, S. Combustion parameters identification and correction in diesel engine via vibration acceleration signal. Appl. Acoust. 2017, 116, 205-215. [CrossRef]

13. Ji, S.; Cheng, Y.; Tang, J. Study on combustion process estimation using frequency information of diesel engine vibration acceleration signal. In Proceedings of the Second International Conference on Mechanic Automation \& Control Engineering, Hohhot, China, 15-17 July 2011; Institute of Electrical and Electronics Engineers: Danvers, MA, USA, 2011; pp. 6122-6126.

14. Andersson, I.; McKelvey, T.; Larsson, M. Detection of Combustion Properties in a Diesel Engine using Block Mounted Accelerometers. IFAC Proc. Vol. 2014, 47, 11866-11871. [CrossRef]

15. Erdiwansyah; Sani, M.S.M.; Mamat, R.; Zikri, J.; Razak, N. Munawir Experimental investigation of vibrations and noise characterization for spark ignition engine. J. Physics: Conf. Ser. 2019, 1262, 012014. [CrossRef]

16. Dawange, S.V.; Kadlag, V.L. A Review Paper on Vibration Analysis of DI Engine. Int. J. Sci. Res. 2015, 4, 759-761.

17. Geng, Z.; Chen, J.; Hull, J.B. Analysis of engine vibration and design of an applicable diagnosing approach. Int. J. Mech. Sci. 2003, 45, 1391-1410. [CrossRef]

18. Szymański, G.M.; Tomaszewski, F. Diagnostics of automatic compensators of valve clearance in combustion engine with the use of vibration signal. Mech. Syst. Signal Process. 2016, 68-69, 479-490. [CrossRef] 
19. Chen, J.; Randall, R.B.; Peeters, B. Advanced diagnostic system for piston slap faults in IC engines, based on the non-stationary characteristics of the vibration signals. Mech. Syst. Signal Process. 2016, 75, 434-454. [CrossRef]

20. Grajales, A.J.; Quintero, H.F.; Cardona, A.; Henao, E.; López, J.F. Engine diagnosis based on vibration analysis using different fuel blends. Diagnostyka. 2017, 18, 27-36. [CrossRef]

21. Chiatti, G.; Chiavola, O.; Palmieri, F. Vibration and acoustic characteristics of a city-car engine fueled with biodiesel blends. Appl. Energy 2017, 185, 664-670. [CrossRef]

22. Penchev, B.; Mihaylov, V. Influence of direct injection of gasoline on the environmental performance of ICE. In Proceedings of the 54th Annual Science Conference of Ruse University, Ruse, Bulgaria, 2015.

23. Xinling, L.; Zhen, H. Emission reduction potential of using gas-to-liquid and dimethyl ether fuels on a turbocharged diesel engine. Sci. Total. Environ. 2009, 407, 2234-2244. [CrossRef]

24. Murugesan, A.; Umarani, C.; Subramanian, R.; Nedunchezhian, N. Bio-diesel as an alternative fuel for diesel engines-A review. Renew. Sustain. Energy Rev. 2009, 13, 653-662. [CrossRef]

25. World Fuel Charter. Available online: https://www.acea.be/uploads/publications/WWFC_19_gasoline_diesel.pdf (accessed on 24 February 2021).

26. PN-EN 14103:2020-06. Standard Products for Processing oils and Fats—Fatty Acid Methyl Esters (FAME)—Determination of the Content of Linolenic Acid Esters and Methyl Ester. 2020, pp. 1-21. Available online: https://sklep.pkn.pl/pn-en-14103-2020-06e. html (accessed on 8 March 2021).

27. Firoz, A.; Saleh, M.; Harun, C. Third Generation Biofuel from Algae. Procedia Eng. 2015, 105, 763-768.

28. Syguła, E.; Koziel, J.A.; Białowiec, A. Proof-of-Concept of Spent Mushrooms Compost Torrefaction-Studying the Process Kinetics and the Influence of Temperature and Duration on the Calorific Value of the Produced Biocoal. Energies 2019, 12, 3060. [CrossRef]

29. Snehesh, S.A.; Dasappa, S. Biomass to liquid transportation fuel via Fischer Tropsch synthesis-Technology review and current scenario. Renew. Sustain. Energy Rev. 2016, 58, 267-286.

30. Li, J.; He, Y.; Tan, L.; Zhang, P.; Peng, X.; Oruganti, A.; Yang, G.; Abe, H.; Wang, Y.; Tsubaki, N. Integrated tuneable synthesis of liquid fuels via Fischer-Tropsch technology. Nat. Catal. 2018, 1, 787-793. [CrossRef]

31. Gill, S.; Tsolakis, A.; Dearn, K.; Rodríguez-Fernández, J. Combustion characteristics and emissions of Fischer-Tropsch diesel fuels in IC engines. Prog. Energy Combust. Sci. 2011, 37, 503-523. [CrossRef]

32. Mancaruso, E.; Sequino, L.; Vaglieco, B.M. GTL (Gas To Liquid) and RME (Rapeseed Methyl Ester) combustion analysis in a transparent CI (compression ignition) engine by means of IR (infrared) digital imaging. Energy 2013, 58, 185-191. [CrossRef]

33. Uludamar, E.; Tüccar, G.; Aydın, K.; Özcanlı, M. Vibration Analysis of a Diesel Engine Fuelled with Sunflower and Canola Biodiesels. Adv. Automob. Eng. 2016, 5, 1000137. [CrossRef]

34. Yang, T.; Wang, T.; Li, G.; Shi, J.; Sun, X. Vibration Characteristics of Compression Ignition Engines Fueled with Blended Petro-Diesel and Fischer-Tropsch Diesel Fuel from Coal Fuels. Energies 2018, 11, 2043. [CrossRef]

35. Grajales, J.A.; Quintero, H.F.; Romero, C.A.; Henao, E. Engine Diagnosis Based on Vibration Analysis Using Different Fuel Blends. Appl. Cond. Monit. 2017, 18, 267-274. [CrossRef]

36. Uludamar, E.; Tosun, E.; Tüccar, G.; Yıldızhan, Ş.; Çalık, A.; Yıldırım, S.; Serin, H.; Özcanlı, M. Evaluation of vibration characteristics of a hydroxyl (HHO) gas generator installed diesel engine fuelled with different diesel-biodiesel blends. Int. J. Hydrog. Energy 2017, 42, 23352-23360. [CrossRef]

37. Ravi, M.; Kumar, K.C.K.V.; Murugesan, A. Certain investigations on the performance of emission, vibration and noise characteristics of C.I engine using biogas and biodiesel as alternate fuel. Int. J. PharmTech Res. 2015, 8, 11-19.

38. Taghizadeh-Alisaraei, A.; Ghobadian, B.; Tavakoli-Hashij, T.; Mohtasebi, S.S. Vibration analysis of a diesel engine using biodiesel and petrodiesel fuel blends. Fuel 2012, 102, 414-422. [CrossRef]

39. Satsangi, D.P.; Tiwari, N. Experimental investigation on combustion, noise, vibrations, performance and emissions characteristics of diesel/n-butanol blends driven genset engine. Fuel 2018, 221, 44-60. [CrossRef]

40. Erdiwansyah; Sani, M.S.M.; Mamat, R.; Khoerunnisa, F.; Rajkumar, A.; Razak, N.; Sardjono, R. Vibration Analysis of the Engine Using Biofuel Blends: A Review. MATEC Web Conf. 2018, 225, 01010. [CrossRef]

41. Li, G.; Gu, F.; Wang, T.; You, J.; Ball, A. Investigation into the Vibrational Responses of Cylinder Liners in an IC Engine Fueled with Biodiesel. Appl. Sci. 2017, 7, 717. [CrossRef]

42. Omar, F.K.; Selim, M.Y.; Emam, S.A. Time and frequency analyses of dual-fuel engine block vibration. Fuel 2017, $203,884-893$. [CrossRef]

43. Reu, P.L.; Rohe, D.P.; Jacobs, L.D. Comparison of DIC and LDV for practical vibration and modal measurements. Mech. Syst. Signal Process. 2017, 86, 2-16. [CrossRef]

44. Vulli, S.; Dunne, J.; Potenza, R.; Richardson, D.; King, P. Time-frequency analysis of single-point engine-block vibration measurements for multiple excitation-event identification. J. Sound Vib. 2009, 321, 1129-1143. [CrossRef]

45. Lyons, R.G. Understanding Digital Signal Processing, 3rd ed.; Pearson Education, Inc.: Ann Arbor, MI, USA, 2011 ; pp. 1-954. 